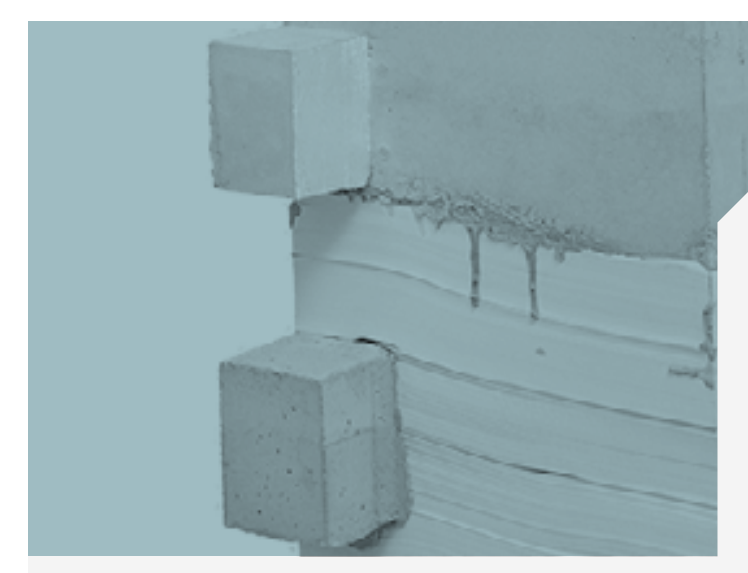

\title{
A ESCRITA DE SI NA LEITURA DO OUTRO - A AUTOFICÇÃO E A MEMÓRIA NO CONTO "ANA C.", DE ADRIANA LUNARDI
}

SELF-WRITING IN THE OTHER'S READING - AUTOFICTION AND MEMORY IN ADRIANA LUNARDI'S SHORT STORY "ANA C."

Vera Lopes Silva*

RESUMO: Este resumo anuncia a análise das relacões entre biografia Lunardi, um dos nove de sua obra Vésperas. Nessas entrevozes da literatura universal (quer personagens - Alice, Ulisses e Sísifo - quer autores - Rimbaud e Machado), encontramos os protagonistas quer Cristina César e Caio de Abreu Fernandes. Suas vidas e obras se entrecruzam, enredadas por outra voz, autoral que também se manifesta no papel de leitora primorosa, fazendo do conto um arquivo imateria da memória. Ricardo Piglia, em O último leitor, question "O que é um leitor?", afirmando ser essa a pergunta da literatura. $O$ conto Ihe un rescritor Caio Fernando Abreu, que, estando à morte, tem a poetisa Ana C Ć́sar como guja ao outro mundo. Apesar de a voz notrisa Anve Cesar cor ouvida ser a de Caio, energe outra, que resgata biografia e estlo do aur, astimes nos bastidos da con do desse artifício o anteparo do enredo que conta sobre esses , fazenco desse ando, conforme o teórico argentino, "a ficcão como uma seres, ch fição". A con . dá por um escritor que se mostra um oscritor-leitor e, porsso, "inquie-

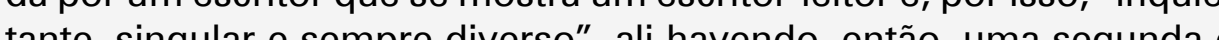
tante, singular e sempre diverso", all havendo, enco, uma segunda anterior instancia da narrativa. Dentro do tenso limite do conto, a au-

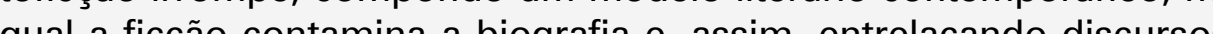
qual a fiç̧a contamina a biografia e, assín, entelaçán.

PALAVRAS-CHAVE: Autoficção; Memória; Leitor; Conto.
* verasesamo@gmail.com

Doutora em Literatura Comparada pela UERJ - Universidade do Estado do Rio de Janeiro.

ABSTRACT: This summary presents the analysis of the relations between biography, autobiography, autofiction and memory, in "Ana C.", one of the nine short stories by Adriana Lunardi in her work Vésperas. In it among voices of universal literature (whether characters - Alice, Ulysses and Sisyphus, or authors - Rimbaud and Machado), we find the protagonists' voices of Ana Cristina César and Caio Fernando Abreu. Their lives and works intertine, entangled by ather authoriat voice, which also manifos itself in the role of an exquiste reader, making the short story an imm in "What is a reader?", claiming that this is the question of literature. The hort istory responds intern. The narrative takes place in the first person, in the voice of the writer Caio Fernando Abreu, who, nea his death, . . vor's biog is Caio's, ant as his gude to the ot vor's biog ra Caio's, a style, as well en itself to be a reader of the (and other) authors, and presents his way ithello infuence the the "fiction as. In sum, it ciction". The work is, then argentine the knowe knowledge of this plot is given by a writer who is a writer-reader and, therefe, "disturbing, singular and always diverse", where we find, then, a second and previous instance of the narrative. Winin the tense limit of the shortory, autofictionarises, composing a contemporany literary modiscours and constituting a memory of the literary.

KEYWORDS: Autofiction; Memory; Reader; Short story. 
Virgínia Woolf, em sua obra O leitor comum, afirma que

qualquer que seja nossa abordagem dos livros, uma batalha solitária nos espera no fim. Há uma negociação a ser cumprida entre escritor e leitor antes que quaisquer procedimentos adicionais sejam possíveis [...]. Nossa primeira tarefa, e isto é muitas vezes suficientemente formidável, é nos assenhorearmos de sua perspectiva.[...] Sozinhos, devemos subir nos ombros dos romancistas e fitar através de seus olhos até, ta mbém, compreendermos em que ordem ele dispõe os va riados objetos comuns que os romancistas estão fadados a observar: o homem e a humanidade; por trás deles a Natureza; e sobre todos aquele poder que por conveniência e brevidade devemos chamar de Deus. ${ }^{1}$

Adriana Lunardi, em seu conto "Ana C.” (parte da obra Vésperas, composta de nove narrativas), nos oferece um forte ombro por sobre o qual nos posicionamos, para que possamos compreender em que ordem ela dispõe o homem e a humanidade.

Assim, estando nessa posição, o leitor de Lunardi tem a visão de um cenário produtivo, dinâmico, instaurado por um movimento a utoral que: a) se encaminha de atos de leitura para a escrita, pondo em evidência duas categorias, a de leitor e a de autor; b) promove reflexões acerca dos conceitos, tão deslizantes , de biografia, autobiografia e autoficção; c) por fim, por meio de tudo isso, se propõe a fazer ficar, para sempre, na memória, a vida de Caio Fernando Abreu e Ana Cristina César, bem como a si mesma, em uma rede de leituras.

Para isso, uma voz autoral se encarna, não como personagem, alguém que se situa como categoria narrativa intra texto, mas como alguém que se situa em uma terceira margem, fazendo-se ema nar pelas leituras que fez e que se apresentam nas linhas do conto e, assim, construindo, além do enredo, uma escrita de si fomentada pelas leituras que fez do outro. Sua ação é a de engendrar o que leu à construção de uma nova ordem, para a qual resgata as vidas dos autores Caio Fernando Abreu e Ana Cristina César (uma circunstância biográfica em que certa responsabilidade com a verdade se faz presente) e, ficcionalmente, faz-lhes ajustes, coloca-as em harmonia, recuperando o que houve entre os dois e construindo o que poderia ter havido, numa tentativa de fazer um ajuste de contas. Trata-se de uma voz que se faz solidária, cheia de dor, compaixão e amor.

Comecemos pela chave que nos permite adentrar no conto: o título. Ele se compõe de um nome, uma assinatura - Ana C. -, referência à poetisa Ana Cristina César (que morreu em 1983), pois é uma reprodução da forma como ela assinava seus textos - escrita completa do primeiro nome e

EM TESE

BELO HORIZONTE

v. 24

N. 1

JAN.ABR. 2018

SILVA. A escrita de si na leitura do outro [...]

P. $300-313$

Teoria, Crítica Literária, outras Artes e Mídias 
2. DIP. Para sempre teu, Caio F, p. 203.

3. DIP. Para sempre teu, Caio F., p. 203 abreviatura do segundo: “Ana C.”. Dessa forma se anuncia a participação dessa pessoa real, transfigurada em uma personagem/voz; concomitantemente, o título também alude ao modo como o autor Caio Fernando Abreu (que morreu em 1996) assinava suas cartas - escrita completa do primeiro nome e abreviatura do segundo: "Caio F.". Em carta a Paula Dipp, de 24 de setembro de 1983, ele se despede: "Um beijo grande. Seu velho amigo, Caio F. (o primo careta da Christiane)", ${ }^{2}$ reportando-se a Christiane, "a garota alemã que escreveu o livro Christiane F., 13 anos, drogada, prostituída, abandonada, o mais novo sucesso editorial na Europa, em que ela revela sua experiência adolescente de se prostituir nas ruas de Berlim para comprar heroína”. ${ }^{3}$ E, assim, uma segunda pessoa se projeta na narrativa para a composição de mais uma personagem/voz.

Passemos ao enredo, que se constitui do último dia de vida de Caio Fernando Abreu, sendo guiado pela amiga Ana Cristina César para o mundo dos mortos, trama que confere ao texto caráter ficcional, quer pela distância temporal que separa biograficamente as duas vidas, quer pelo caráter transcendente em que a cena se traduz.

Ocorre que, para que essas duas vozes fossem biográfica e ficcionalmente manifestas, foi preciso que alguém as buscasse, lesse suas obras, lançasse sobre elas um olhar observador, decodificador, seletivo, orga nizável, criativo, enfim. Foi preciso que alguém embaralhasse, na ficção, a biografia. $\mathrm{O}$ título enuncia, então, subjacente, uma voz autoral que ali já se mostra, começando a exibe-se por essas suas leituras e anunciando um enredo cuja composição será alimentada e esteticamente constituída por elas. Nesse primeiro momento, já fazemos contato com alguém que conhece a amizade o grau de amizade, que havia entre Caio Fernando Abreu e Ana Cristina César, relação passível de comprovação, como se lê na carta em que Ivan Matos, amigo de Caio, relata a Paula Dip: "Ele [Caio] ficou muito abalado com o suicídio da Ana C. porque eles estavam meio brigados na época e a sensação dele era de remorso por não ter reatado plena mente com ela antes". ${ }^{4}$, para dar conta desse grau de amizade real, essa voz autoral a reescreve esteticamente, desde o título, acoplando o nome de um na forma de assinatura de ambos.

Vemos desenhada assim a absorção da biografia pela forma poética e o deslizamento de gêneros e conceitos: embrenhando-se as vozes de Caio Fernando Abreu e Ana Cristina César e a de outra, autoral, embrenham-se também biografia, a utobiografia, autoficção, modalidades que deslizam pela narrativa de Adriana Lunardi, perfazendo uma proposta de trajeto de leitura (tanto o trajeto que foi feito pela autora por outros escritos, como o que fazemos

$\begin{array}{llllll}\text { EM TESE } & \text { BELO HORIZONTE } & \text { v. } 24 & \text { N. } 1 & \text { JAN.-ABr. } 2018 & \text { SILV. A escrita de si na leitura do outro }[\ldots]\end{array}$

Teoria, Crítica Literária, outras Artes e Mídias 
5. Usaremos o termo autor para designar a pessoa Adriana Lunardi o termo escritora para designa aquela que exibe $o$ arquivo de leituras que promove a constituição da trama.

6. VIEGAS. Adriana Lunardi: assinatura, filiação e inscrição na cena literária. dela - uma escritora $-{ }^{5}$ nesse seu escrito) e de escrita, o que resulta numa escrita dela sobre si mesma, entalhada na leitura do outro. Assim, delinearemos um percurso de sinalizações dessas modalidades, no intuito de elucidar de que forma a voz autoral se constitui como um objeto de construção imagética para o leitor do conto. Como essas modalidades se a nunciam aqui e ali no decorrer da narrativa, vamos caminhando por pistas que propiciem a percepção de sua presença questionada ou reiterada.

Atendo-nos aos movimentos feitos pela voz autoral, podería mos considerar que o conto trataria da biografia, um enunciado, de Caio Fernando Abreu, reportando a parte de sua vida e reeditando algo de sua imagem, tendo em vista que o enredo nos relata seus últimos momentos de vida Ali está (embora não nomeado) Caio Fernando Abreu, em carne e osso e voz. Indícios de sua existência percorrem o conto, conforme enumera Ana Cláudia Viegas: "Várias referências textuais - Audrey Hepburn, a contracultura, o muro caiado, a rainha de copas do tarô, o 'mapa para sempre incompleto' das viagens pelo mundo, o vírus e a peste - nos permitem nomear esse narrador como o escritor Caio Fernando Abreu, morto em consequência da Aids em 1996" [...]. ${ }^{6}$ Por exemplo: faz parte do enredo uma cena em que, indo Caio para o hospital, sente falta de Zelda, sua gata: "Zelda não está por ali. Gatos nunca se despedem.
Poupam-nos de nossas próprias breguices e, solenes, nos ensina $m$ a ta mbém falsear dignidade". ${ }^{7}$ Essa referência ao felino serve-nos aqui como indício de certo caráter biográfico na composição do conto, pois é material registrado em um trecho da carta escrita por Caio e dirigida a Sonia Coutinho:

\section{Sampa 17, digo 18.05 .82}

O mais são algumas quadraturas emocionais, mas tudo bem. Abandonei a psicanálise, ou melhor: troquei pela dança. Há dois anos que bailo, bailo, bailo.

Moro sozinho com Zelda Fitzgerald, minha gata (adora gim), e às vezes sinto muita saudade de você. Me dá notícias qualquer hora, de repente. Te gosto sempre.

\section{Muito carinho. Um beijo do}

Caio Fernando Abreu. ${ }^{8}$

Ali há também evidências de Ana Cristina César: a assinatura no título; o relato da morte da a miga feito pelo narrador ("Quando a tendi o telefonema avisando que Ana C. tinha se a tirado do sétimo andar, tive a sensação de que aquela notícia já era antiga." ${ }^{\prime}$ ). Dada a grande amizade que houve entre esses dois autores, a presença desse nome complementaria a biografia de Caio Fernando Abreu e,

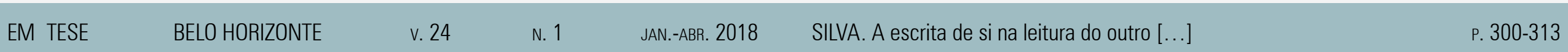


10. DIP. Para sempre teu, Caio F, p. 194.

11. DIP. Para sempre teu, Caio F., p.

12. DIP. Para sempre teu, Caio F, $\mathrm{p}$.

assim, a escolha não teria sido aleatória para uma suposta biografia. Paula Dip, ${ }^{10}$ comentando sobre a a mizade entre eles, afirma: "Como os escritos de Caio, os poemas de Ana C. desnudavam uma alma inteiramente só”. ${ }^{11}$ E acrescenta, sobre a intrínseca relação entre os dois: "Ela [Ana Cristina César] era praticamente um Caio F. de saias". ${ }^{12}$

No entanto, apesar de esses registros serem ingredientes da obra, a forma como ali se orga nizam não é objetiva nem documental; não há intenção de busca às fontes e de provas comprobatórias (alguém, de carne e osso, externo ao relato, disposto a narrar a trajetória de vida de um ser, também de carne e osso, por meio de evidências, documentos, etc.), de maneira a fugir, digamos, da fusão do gênero romanesco à história de vida, que faria a composição de uma biografia

E, mesmo que a caracterização ou definição do texto biográfico seja deslizante (como, aliás, o é qualquer gênero) atendo-nos ao conto em estudo, é fácil perceber como a obra se desvia do perfil dessa forma textual, dado o fato de que, por exemplo, a voz narrativa se dá em primeira pessoa, o que já encaminharia o texto para a autobiografia, que também pressupõe a fusão do gênero romanesco à história de vida, mas que, segundo Wander Melo Miranda, quando trata de Graciliano Ramos e Silviano Santiago, é um ato de discurso literariamente intencionado:
Tal postura supõe a delimitação do campo de interesse à abordagem do funcionamento específico dos mecanismos internos de organização textual, sem desprezar sua articulação com um determinado regime de leitura no âmbito do sistema literário e social, a fim de estabelecer os traços configuradores de uma modalidade narrativa que, apesar de suas características particulares, mantém afinidades com outras modalidades vizinhas. [...] Na verdade, o objeto profundo da autobiogra fia é o nome próprio e o trabalho sobre ele e sobre a assinatura, fundamento do que Philippe Lejeune chama de pacto autobiográfico, isso é, a firmação da identidade autor-narrador-personagem, remetendo em última instância ao nome do autor na capa do livro. ${ }^{13}$

A possibilidade, então, de se encontrar uma a utobiografia no conto em estudo seria também logo descartada, haja vista que não se evidencia a afirmação da identidade autor-narrador-personagem; e ainda que o narrador, relatando seus instantes finais de vida, só poderia fazê-lo (na esteira de Machado) como defunto-autor ou um autor-defunto; dados que, de imediato, transferem a obra para o campo predominante da ficção. Diante do exposto, fica claro haver um agente construtor da obra, do título, do enredo, das personagens, do espaço, do tempo. Trata-se da existência de uma autoria que assina a obra e dá voz a um narrador, este que, embora pertencente ao mundo real, vai ali ter sua
13. MIRANDA. Corpos escritos, p.26-

$\begin{array}{llllll}\text { EM TESE } & \text { BELO HORIZONTE } & \text { v. } 24 & \text { N. } 1 & \text { JAN.-ABr. } 2018 & \text { SILVA. A escrita de si na leitura do outro }[\ldots]\end{array}$

Teoria, Crítica Literária, outras Artes e Mídias 
14. ECO. Seis passeios pelos bosques da fiç̧ão, p. 42 trajetória de vida organizada de outra maneira, passando a constituir-se como um ser de papel. Essa construção, assim, (embora se pautando em indícios que vinculariam a narrativa a um relato sobre vidas reais) põe em destaque outro elemento, diga mos, ta mbém parte do mundo real, o autor, que se mostra em seu papel de escritora, e que, assim, se apresenta na obra com outra configuração.

Pode-se pensar que essa voz autoral se constrói como um autor-modelo, categoria tratada por Umberto Eco: aquele que "se revela na maneira como organiza a história: não através de um enredo, mas através de um discurso" ${ }^{14}$ Acrescenta-se, porém, que, acentuada mente, esse autor-modelo se interpõe à narrativa, desejando que o recebedor da sua obra reconheça e aprecie as estra tégias de construção advindas de alguém que, previamente, se postou como um leitor de outras obras e teve a possibilidade de transformar esteticamente aquilo que leu, ou seja, apresenta-se um leitor-escritor, um escritor-leitor. Um enredo marginal se apresenta, composto de uma trajetória de leituras, e se oferece ao desnudamento, num processo em que um escritor se autorrevela, fazendo a escrita de si mesmo por meio do desnudamento que faz das leituras de outrem.

Sendo assim, o destaque da narrativa não se dá apenas por uma elaboração harmoniosa de categorias (um narrador em 1. a pessoa, que narra seus instantes finais de vida, passados em um hospital, junto a enfermeiros e uma a miga de além-vida...). Trata-se de uma voz autoral, que exibe seu arquivo de leituras, elucidando sua busca em outros, do material a ser transformado em ficção. Trata-se da demonstração da concepção da obra e, portanto, daquele que a concebe, mas não biografica mente, e, sim, como uma imagem, a de escritora.

Desse modo, mesmo que esteja se mostrando, estão ausentes seu nome, dados sobre si, vestígios de comprovação do real de sua vida, além de que, e principalmente, como já afirma mos, não se posiciona no âmbito do texto, mas em outra margem, não configurada nas categorias, digamos, internas à escritura, como o são narrador e personagem, mas configurada no discurso.

Então, embora resvale também em uma produção autobiográfica (agora no que tange à autora), parece direcionar-se mais para a autoficção, haja vista os fortes círculos metafóricos que circulam entre fato e ficção. Essa percepção se dá na esteira da conceituação feita por Luciene Almeida de Azevedo, segundo a qual a autoficção é entendida

como um apaga mento do eu biográfico, capaz de constituir -se apenas nos desliza mentos de seu próprio esforço por contar-se como um eu, por meio da experiência de produzir-se

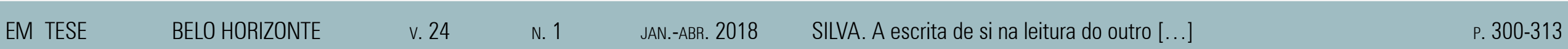

Teoria, Crítica Literária, outras Artes e Mídias 
15. AZEVEDO. Autoficção e literatura contemporânea, p. 35.

16. AZEVEDO. Autoficção e literatura contemporânea, p. 43. textualmente. Eu descentralizado, eu em falta que preenche os vazios do semi-oculto com as sinceridades forjadas que escreve. $^{15}$

Ou seja, na construção dos espaços, do tempo, do enredo e dos personagens, há ta mbém a construção da imagem da autora, produz-se textualmente, como a de alguém que lê e usufrui de sua leitura para a construção de obras, ou seja a imagem de uma escritora, "cuidadosamente construída qua nto cada um dos 'eus' criados no papel”. ${ }^{16}$ Isso se dá pelas citações, intertextualidades de vária ordem demonstradas no decorrer do conto. São leituras das biografias - textos documentais -, de Caio Fernando Abreu e Ana Cristina César e também da(s) ficção(ções) construída(s) por esses a utores e da(s) ficção(ções) construída(s) sobre esses a utores - pelo olhar de outros ou pelo próprio olhar dos dois sobre si (pelas cartas de Caio, por exemplo, vê-se esse "auto-olhar"). As leituras realizadas por Caio também apa recem entremeadas às leituras da voz autoral. Esse corpus intrincado de leituras espelha a autora em seu processo de invenção da cena final vivida por Caio Fernando Abreu, com ajustes, (re)criações, traduzindo sensações, objetivos e planejamentos de uma escritora. Portanto, esse corpus espelha sua imagem de escritora, fazendo de sua escrita uma escrita de si, calcada na leitura do outro.
Segundo Ana Cláudia Viegas, referindo-se aos contos de Vésperas,

ao misturar narradores, escritores e personagens, Adriana borra os limites entre ficção e biografia, arte e vida, e compõe a si mesma como personagem. Que imagem de si a autora Adriana vai traçando ao criar seus textos a partir dessas outras vozes? [...] Ao invés de fruto de uma originalidade absoluta, a criação literária se apresenta, nessa obra, como resultado de diversas leituras e reescrituras, embaralhando na trama final dados biográficos das autoras, personagens, frases, referências das mais diversas ordens. ${ }^{17}$

Registra-se a obra, dessa forma, como uma autoficção, tendo em vista o fa to de que esse gênero pode se instaurar na linha, com voz autoral mais colada em narrador, mas que pode também ser incrustada no texto via extralinha, em outras margens, não exatamente na exposição de uma primeira pessoa, assim como o faz Lunardi. Ela destrói qualquer pacto que poderia ser feito ante uma leitura biográfica (no que se refere aos dois nomes sobre os quais ela discorre); ou ante uma leitura autobiográfica (no que se refere ou à primeira pessoa de Caio Fernando Abreu ou a si mesma, em sua condição de autora que se deixa mostrar em sua função de escritora). Diferentemente disso, ela se propõe a um pacto para o autoficcional, porque faz
17. VIEGAS.Com a palavra, o autor exercícios de crítica biográfica na contemporaneidade, p.35.
EM TESE
BELO HORIZONTE
v. 24
N. 1
JAN.-ABR. 2018
SILVA. A escrita de si na leitura do outro [...]
P. 300-313

Teoria, Crítica Literária, outras Artes e Mídias 
prevalecer a ficção, construindo sua imagem na mesma dimensão, digamos, em que o faz para seus personagens: trata-se da imagem de uma leitora, sensível diante não só do caráter inevitável da morte mas dos desencontros irrecuperáveis da vida.

Nem nos deteremos aqui na consideração de que os contos de Véspera são a nunciados publicamente como produto de uma Bolsa da Biblioteca Nacional, a que se vincula uma pesquisa literária sobre autoras, produção da qual faz parte o conto em a nálise como da autoria de Adriana Lunardi. Nem no fato de que, em sua oficina de criação literária ministrada na UERJ, no primeiro semestre de 2013, Lunardi tenha demonstrado que o processo de construção de si como artista da palavra se dê no âmbito de outros autores e obras, caminhos para o encontro de temas, de formas, de seu próprio estilo, deixando claro o seu pacto de filiação e orientando os alunos a terem a mesma atitude. Estamos nos atendo principalmente ao cenário de sua escritura, na qual se insere um sujeito, configurado nas imagens de leitora e escritora; e ao fato de que, nesse duplo/uno, ela se revela a nós como uma alma sensível, que empreende, por sua capacidade de ficcionalizar, a emergência de si, que, sobressaída das palavras ficcionais do narrador, tece um encontro entre Caio Fernando Abreu e Ana Cristina César, para consertar o desencontro entre eles que se deu biograficamente, em vida, e para dar-lhe um final, diga mos, feliz. Há, assim, um jogo entre o referencial e o ficcional - uma autora contratada para uma produção literária e que é leitora de dois autores - permite que se emane dos capítulos uma voz autoral que é leitora de dois autores. O pacto se dá entre voz autoral e leitor, este guiado por essa persona que está fora da ficção, numa terceira margem intrínseca ao texto. É preciso que o leitor tenha aderência a essa relação um tanto regida pelo princípio da veracidade, um tanto regida pelo princípio da invenção, uma das características de um texto autoficcional.

Essa persona lhes dará uma nova oportunidade, e também a si mesma, pela nova palavra, de enfrentar o desconcerto do mundo diante da implacabilidade da morte. Escreve-se, dessa forma, escreve a si mesma. Trata-se de, ficcionalmente, atender a um desejo autoral de corresponder-se, como leitora-escritora e escritora-leitora, com a produção de, e sobre, Caio Fernando Abreu e Ana Cristina César, no sentido de dialogar com suas biografias, suas crenças, seus gestos, suas obras, reconstruindo, para sempre, a trajetória de vida desses autores bem como sua trajetória de leitora que se manifesta na escrita. Leyla Perrone-Moisés, em seu artigo "A criação do texto literário", considera que, "em sua gênese e na sua realização, a literatura aponta sempre para o que falta, no mundo e em nós. Ela empreende dizer as coisas como 
são, faltantes, ou como deveriam ser, completas. Trágica ou epifânica, negativa ou positiva, ela está sempre dizendo que o real não satisfaz"

Alguns aspectos que podem ser considerados como faltas saltam da imagem construída da voz autoral no conto "Ana C.": o desencontro em vida entre Caio Fernando Abreu e Ana Cristina César; o suicídio dessa jovem poetisa a ausência para sempre desses dois seres, cuja vida foi sempre uma busca frustrada de harmonia com o mundo. $\mathrm{O}$ conto de Lunardi harmoniza esses personagens entre si, dá-lhes um final amoroso, mas de forma que os três, Caio, Ana Cristina e a voz autoral, encenem novos papéis.

Por essa estratégia descrita, a narração possibilita a manutenção da memória de Ana Cristina César e de Caio Fernando Abreu. Isso se faz em um entrelugar entre o fato e a ficção -, juntamente à memória da voz autoral, compositora que é de sua obra e de sua imagem. Ficcionalmente, o desejo da autora de que as vozes de Caio e Ana Cristina permaneçam, mesmo que, sob novo enfoque, se acopla ao próprio desejo performático de si, de maneira que ela própria é um ator no cenário discursivo. Entre os muitos aspectos que exemplificam a performance dessa autoria, trataremos de três: o primeiro deles, a competência de escritora, que consegue transformar uma fala que produzia um efeito de sentido em outra, com outro efeito de sentido, para traçar a orientação emocional do narrador Caio Fernando Abreu; o segundo, a competência de absorver o discurso do outro, no caso, o de Caio Fernando Abreu; o terceiro, a realização, pela ficção, de uma nova cena biográfica: pelo espírito místico de Caio, se dará a ele uma nova chance de reencontro com Ana Cristina. Esclarecemos que esses aspectos são indissociáveis e, neste trabalho, se apresentam separadamente apenas na tentativa de tornar mais didático este estudo. Também explicitamos ter havido uma seleção desses aspectos entre os constituintes da obra, como as alusões, e, entre elas, aquelas que também nos pareceram vir ao encontro de nossas reflexões, embora todos sejam muito importantes, como referências a Gertrude Stein ou a Homero.

Primeiramente, a escritora faz ecoar a voz do autor, puxando uma informação que Caio dá a sua amiga Vera Antoun, em carta de abril de 1974, pela qual demonstra tanto a leitura do autor como a sua própria:

London, London — insone quase manhã de abril de 1974

Leio Alice's adventures in Wonderland - também conhecido como Alice no País das Maravilhas - em inglês - uma batalha vencida pouco a pouco. Homero rouba porradas de livros sobre Gertrude Stein e Alice B. Toklas - quer escrever um ensaio sobre o caso das duas. Na outra página te mando

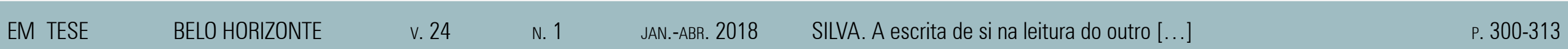

Teoria, Crítica Literária, outras Artes e Mídias 
um poema que escrevi há alguns meses. O título é uma tampinha de caixa de sal - reproduzo o desenho porque, no momento, não tenho nenhuma das referidas caixas à mão.

\section{Te beijo}

Te espero em carta.

\section{Caio}

(here comes the sun little darling it's all right now) ${ }^{19}$

Essa expressão - "uma batalha vencida pouco a pouco" - será posta pela escritora não como a dificuldade de se ler a obra de Carroll, conforme se apresenta no trecho da epístola, mas como a dificuldade vivida pelo autor em seu último dia, narrado no conto, uma batalha entre morte vida, entre caos e cosmo, sem se saber o que é, na verdade, o caos e o cosmo, se morte ou vida. Cremos que nenhuma obra seria mais pertinente para acompanhar os últimos instantes de vida do narrador do que Alice no País das Maravilhas, com seu nonsense não alea tório nem despropositado. Os jogos de espaços e tempos vividos pela pequena personagem são transpostos com nova configuração para o conto de Lunardi. Ali, a mbulância, elevador de hospital, paraíso se misturam em vertigem semelhante às vividas por Alice. Assim, emocionalmente Caio é uma Alice, a mbos dessimétricos; ele, espelho do que descreve: "Alice parecia comprida demais, loira demais. O ar malévolo de suas expressões brigadas com a Alice que eu tinha desde a infância e que, anos depois, vi materializar-se na face de Audrey Hepburn". ${ }^{20}$

Em segundo lugar, ainda pelo eco da voz do autor, a escritora faz com que o tom de Caio Fernando Abreu, admiravelmente, impregne a narrativa - sua voz é triste, melancólica, com intensa força descritiva. Ilustremos essa contração do estilo de Caio pelo domínio da escritora em dois trechos (entre os muitos que se poderiam realçar) - um, parte de uma carta de Caio, o real, a Sérgio Keuchgerian, e outro, Caio, o narrador de Lunardi:

Na cidade alagada

27 de janeiro de 1987

$16 \mathrm{~h} 20 \mathrm{~m} ;[. .$.

Teve uma noite de lua cheia - e era midsummer, pleno verão, não havia noite, só duas horas de penumbra crepuscular - que saí a caminhar em busca de alguém para conversar Dizer ôi (ou hei, em sueco), ou Inteprätesvenska ("não falo sueco") que fosse. E nada, não encontrei ninguém. Caí (pode?) no meio do asfalto chorando. Arranhei as unhas no asfalto de pura solidão. E aquela lua cheia enorme lá em cima, e os

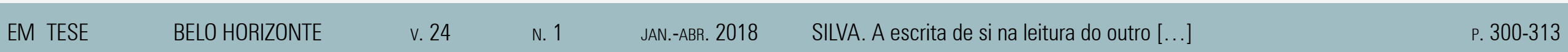

Teoria, Crítica Literária, outras Artes e Mídias 
bosques atrás, com o castelo de verão do rei - tudo parecia sinistro. Parecia que eu ficaria para sempre lá, ao lado do Polo Norte, e que isso não tinha o menor sentido. ${ }^{2}$

Antes de as portas se fecharem, levanto com pesar as pálpebras para o céu azul de fevereiro. A luz me intimida e cega o pouco ainda vejo. A mim só resta imaginar o flamboaiã explodindo flores alaranjadas ao sol e muro caiado que reserva a frieza necessária para enfrentar um dia de verão. ${ }^{22}$

Ambos os excertos trazem uma cena em que o "narrador" se vê diante de um cenário da natureza vinculado a seu interior. Quaisquer que sejam os componentes descritos que descortinam a cena, eles promovem sensação de dor: a frieza, tomada pela cor, distância e enormidade da lua insere-o em um misto de maravilhamento e solidão; e o calor, tomado por intensa luz, insere-o em outro, mas o mesmo, maravilhamento e solidão.

Além dessas duas a mostragens da performance da escritora-leitora, há de se considerar sua também competência em substituir a biografia pelo estético, acolhendo seu próprio desejo de, ficcionalmente, atender a um desejo de Caio Fernando Abreu - o de que Ana Cristina tivesse um amparo, um perdão divino, como se vê em missiva a Jacqueline Cantore:

\section{A Jacqueline Cantore \\ Porto, $1^{\circ}$ de novembro de 1983 \\ M'r'len,}

ótimo receber tua(s) carta(s) hoje de manhã. Não sei se tenho muito o que dizer, também estou ainda em estado de choque. A gente não podia imaginar que Ana realmente conseguisse 41. Ou podia? Primeiro chorei e senti medo e pena. Deu vontade de deitar, dormir três meses. Aí reagi, tomei banho, fiz a barba, botei uma roupa bem limpinha e fui assistir ao último dia do Leiteiro. Que foi lindo. A casa cheia e a plateia aplaudindo em pé no final. Clélia (que melhorou incrivelmente) empacou no final e repetia, com cara de louca: "Eles vêm nos matar porque nós sobrevivemos ao fim do mundo." O tempo todo eu sentia que, se tivesse algo a dizer (ainda) para Ana C., estava tudo naquele texto. Uma choradeira coletiva nos camarins depois.

E então sair com I. - tão lindo, mais lindo ainda -, tomar um vinho, depois vir dormir. E não conseguir: na minha cabeça, Ana C. parada à beira de uma janela. Pensamentos mórbidos: o que ela teria sentido um segundo antes de se jogar no espaço. Depois do choque, certa raiva. Com que direito, Deus, com que direito ela fez isso? Logo ela, que tinha uma arma
21. ABREU,Cartas, 2002, p. 128.

22. LUNARDI, Vésperas. 2002, p.43.
EM TESE
BELO HORIZONTE
v. 24
N. 1
JAN.ABR. 2018
SILVA. A escrita de si na leitura do outro [...]
P. 300-313

Teoria, Crítica Literária, outras Artes e Mídias 
para sobreviver - a literatura - , coisa que pouca gente tem. Pedi a Deus que não permitisse que ela ficasse muito tempo no limbo onde ficamos suicidas. Terá ouvido? Deus não andará com aquela surdez provocada pela poluição sonora? ${ }^{23}$

O pedido e a dúvida de Caio - "Pedi a Deus que não permitisse que ela ficasse muito tempo no limbo onde ficam os suicidas. Terá ouvido?” - são resolvidos na narrativa de Adriana Lunardi. Isso porque, estando Caio próximo à morte, quem vem resgatá-lo para outra vida é Ana C.

Um roçar suave envolve minha mão esquerda, como se alguém a acariciasse. Penso em Anita, de quem não ouço a voz mas imagino próxima, vigilante. Meus dedos tentam responder ao afago e entrelaçam, surpreendentemente, não a carne macia de Anita, mas uns dedos longos e frios como pedras de gelo. [...] A mão agora segura meu ombro. $\mathrm{O}$ contato frio já não produz o mesmo desequilíbrio de antes, embora ainda me sinta um barco bêbado que aderna. Espio por uma fresta da pálpebra esquerda e vejo lentes escuras, levemente convexas, investigando se por acaso ainda respiro. Não são os óculos de Ginsberg, desta vez. Há um jeito brincalhão por trás daquela camada de plástico, um jogo de esconde-esconde, de a migo-oculto, na armação quase grande demais para o rosto que aos poucos vou reconhecendo, cheio de dúvidas e inseguranças, mas cada vez mais certo de estar diante do olhar eternamente encoberto de Ana C. ${ }^{24}$
Esse encontro sensível, a moroso, que já reconcilia os dois escritores, mostra-os gentis, infantis, lúdicos, nessa interlocução habilmente descrita como uma brincadeira entre inocentes, entre crianças - um jogo de esconde-esconde. A palavra eternamente ga rante o estado de morte em que se encontra a amiga; mas nada ali a nuncia que ela estaria "no limbo onde ficam os suicidas". Deus (a escritora) teria, então, atendido ao desejo de Caio (esteticamente).

Essa atitude poética se repete pelo convite que a poetisa faz a ele, para que deixe a vida, quando o narrador Caio é convidado lirica mente para deixar o mundo dos vivos: "Abandone o navio das palavras, ouço-a dizer naquela voz levemente embargada, respirando entre as sílabas, fazendo de cada fala poesia". ${ }^{25}$

As vozes de Ana Cristina e de Caio estão, assim, agregadas à da voz autoral: trata-se de uma referência ao belo poema de Ana C.-

Recuperação da adolescência

"é sempre mais difícil

ancorar um navio no espaço"26

26. CÉSAR. A teus pés, p. 118.

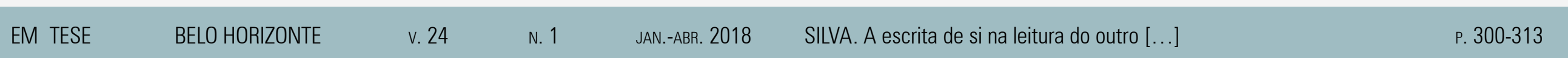

Teoria, Crítica Literária, outras Artes e Mídias 
27. ABREU. Primeira carta para além os muros; Segunda carta para alén os muros, Ultima carta lém dos muros, p. 200. seguro, mas - para lembrar Ana C., que me deteve à beira da janela - como não se pode ancorar um navio no espaço, ancora-se neste porto". ${ }^{27}$ Ambos os textos são leitura da voz a utoral, que, nesse momento, os une, eternamente, pelo discurso literário, por meio de seus fazeres poéticos. O paraíso oferecido então a Caio, para o qual o guiam as mãos de Ana C, é um espaço sem dor, com praias, paisagem que nunca se cansará de enxergar e pela qual ele opta: "A confusão me deixa cansado. Quero voltar ao lugar de antes, sua luz âmbar e sua ausência de dor." "Por entre os aventais, procuro Ana C. e já não a encontro. Chamo por ela, que logo responde, acariciando-me com sua mão de gelo". ${ }^{28}$

E a ele chega junto essa voz autoral, que, assim, (des)registra tanto a biografia dos autores como suas obras e as obras sobre eles. E, ainda e fundamentalmente, coloca-se no mesmo arquivo de memórias, pois nele se insere como escritora que, falando de outros, fala de si - fazendo, na leitura do outro, a escrita de si.

O que se vê no decorrer da trama "Ana C." é uma confissão da experiência de uma autora como leitora, e, decorrente disso, a confissão de sua experiência como escritora de literatura. Isso significa que sua experiência de leitura, que seria componente importante para a construção de uma biografia, se manifesta metaforica mente, como autoficção. Nesse processo, os temas a mizade, a mor, morte, vida saem da vida comezinha e ganham o estatuto do poético. É por ele que conseguimos enxergar uma voz autoral que se compadece da dor exposta na biografia de Caio Fernando Abreu ante a morte de Ana Cristina César. Como escritora ela pode reverter esse quadro e, assim, engendra uma forma de levá-los ao paraíso. O real, os elementos do biográfico, tornam-se vestígios para a construção de imagens que saem do sofrimento e se aliviam ficcionalmente, atendendo a um desejo que consta da biografia de Caio Fernando Abreu, lido (ou criado?) pela escritora. Essa linha tênue e fina é o cerne dessa construção.

Nesse estatuto, pois, a autoficção irrompe, compondo esse modelo literário que se manifesta na contemporaneidade, no qual a biografia é conta minada pela ficção e, assim, se entrelaçam discursos literários para uma memória do literário. Essa memória se dá, tendo em vista que a cadeia de leitores se amplia: a escritora que leu Caio Fernando Abreu e Ana Cristina César é lida por leitores que já leram ou serão estimulados a ler os dois autores.

Piglia afirma que a pergunta “o que é um leitor?” é, sem sombra de dúvida, a pergunta da literatura. Essa pergunta a constitui, não é externa a si mesma, é sua condição de existência. "E a resposta a essa pergunta - para benefício de todos nós, leitores imperfeitos porém reais - é um texto: inquietante, singular e sempre diverso" ${ }^{29} \mathrm{~A}$ consideração

$\begin{array}{llllll}\text { EM TESE } & \text { BELO HORIZONTE } & \text { v. } 24 & \text { N. } 1 & \text { JAN.-ABr. } 2018 & \text { SILVA. A escrita de si na leitura do outro }[\ldots]\end{array}$

Teoria, Crítica Literária, outras Artes e Mídias 
de Piglia expande-se e aprofunda-se em Ana C., tendo em vista que se manifesta ali uma escritora-leitora, ou seja, a condição da existência desse conto se dá no bojo da própria literatura: ao longo dos parágrafos, acompanhamos a construção e o resultado do projeto de um autor que se arvora em seu arquivo de leituras, de forma a, assim, mostrar seu rosto de escritor, que se dá a conhecer por uma atitude, clara e assumida, de quem tem consciência de seu papel a utoral, em um contexto que o faz ser comprometido com uma escrita que se revele e o revele.

\section{REFERÊNCIAS}

ABREU, Caio Fernando. Cartas. Rio de Janeiro: Aeroplano, 2002.

ABREU, Caio Fernando. Primeira carta para além os muros

Segunda carta para além os muros; Última carta para além dos muros. In: Pequenas epifanias. Rio de Janeiro: Agir, 2006. p. 106-114; 199-201.

AZEVEDO, Luciene Almeida de. Autoficção e literatura contemporânea. Revista brasileira de Literatura Comparada Niterói, v. 10, n. 12, 2008, p. 31-50. Disponível em: <http:// revista.abralic.org.br/index. php/revista/article/view/179/182> Acesso em: 15 fev. 2018.

CÉSAR, Ana Cristina. A teus pés. São Paulo: Brasiliense, 1993. [1 $1^{\mathrm{a}}$ ed. 1982].

DIP. Paula. Para sempre teu, Caio F. Carta, conversas, memórias de Caio Fernando Abreu. Rio de Janeiro: Record, 2011.
ECO, Umberto. Seis passeios pelos bosques da ficção. São Paulo: Companhia das Letras, 1994.

FAEDRICH, Anna. O conceito de autoficção: demarcações a partir da literatura brasileira. Itinerários, Araraquara, n. 40, jan./jun. 2015, p. 45-60. Disponível em: <https://periodicos.fclar.unesp. br/itinerarios/article/download/8165/5547>. Acesso em: 12 out. 2018.

LUNARDI, Adriana. Vésperas. Rio de Janeiro: Rocco, 2002.

MIRANDA, Wander Melo. Corpos escritos. São Paulo: Edusp: Belo Horizonte: UFMG, 1992

PERRONE-MOISÉS, Leyla. A criação do texto literário. In: Flores da Escrivaninha. São Paulo: Companhia das Letras, 1990

PIGLIA, Ricardo. O último leitor. São Paulo: Companhia das Letras, 2006.

VIEGAS, Ana Cláudia. Adriana Lunardi: assinatura, filiação e inscrição na cena literária. (texto inédito)

VIEGAS, Ana Cláudia. Com a palavra, o autor - exercícios de crítica biográfica na contemporaneidade. Cadernos de estudos Culturais, Campo Grande, v. 2, 2010, p. 09-24. Disponível em: < http://seer.ufms.br/index.php/cadec/article/view/4484> . Acesso em: 12 out. 2018

WOOLF, Virgínia. O leitor comum. Rio de Janeiro: Graphia, 2007.

Recebido em: 31-03-2018. Aceito em: 12-10-2018 